\title{
Diversified Use of Byproducts of Sugarcane and Cotton - A Review
}

\author{
S.S. Shree Harsha Kumar* , G. Prakasha, D.C. Hanumanthapa and Sharanappa Kuri \\ Department of Agronomy, University of Agricultural Sciences, GKVK, Bengaluru, \\ Karnataka, India \\ *Corresponding author
}

\begin{tabular}{|l|}
\hline Ke y w o r d s \\
$\begin{array}{l}\text { Sugarcane and } \\
\text { Cotton, } \\
\text { Byproducts }\end{array}$ \\
\hline Article Info \\
\hline $\begin{array}{l}\text { Accepted: } \\
\text { 12 February } 2018 \\
\text { Available Online: } \\
\text { 10 March 2018 }\end{array}$ \\
\hline
\end{tabular}

Keywords

Sugarcane and

Cotton,

Byproducts

10 March 2018

A B S T R A C T

Sugarcane is the world's predominant commercial crop. In the world it is cultivated on an area of $23.8 \mathrm{~m}$ ha with a cane production of 1.69 billion tonnes. In India, sugarcane occupies an area of $4.3 \mathrm{~m}$ ha with a total cane production of $300 \mathrm{~m} \mathrm{t}$ and productivity of $77 \mathrm{t} \mathrm{ha}^{-1}$. In Karnataka, it is grown on an area of $0.33 \mathrm{~m}$ ha with a production of $30 \mathrm{~m} \mathrm{t}$ and productivity of $88 \mathrm{t} \mathrm{ha}^{-1}$.Byproducts derived from sugarcane include trash, bagasse, molasses and pressmud with annual production of 12-15 $\mathrm{m} \mathrm{t}$ of trash, 75-90 $\mathrm{m} \mathrm{t}$ of bagasse, $10-12 \mathrm{~m} \mathrm{t}$ of molasses and 8-10 $\mathrm{m} \mathrm{t}$ of press mud in India.Cotton plays a vital role in the textile industry.Indi having largest area under cotton ( $9 \mathrm{~m} \mathrm{ha}$ ) constituting $26 \%$ of total world cotton area, presently produces $4.59 \mathrm{~m} \mathrm{t}$ ( 27 million bales) which constitutes $18 \%$ of the world cotton production. Byproducts of cotton include stalk, seed, oil and meal.

\section{Introduction}

Sugarcane is tall perennial true grasses of the genus Saccharum, tribe Andropogoneae. Native to the warm temperate to tropical regions of South Asia, they have stout jointed fibrous stalks that are rich in sugar, and measure two to six metres (6 to 19 feet) tall. All sugar cane species interbreed, and the major commercial cultivars are complex hybrids. Sugarcane belongs to the grass family
(Poaceae), an economically important seed plant family that includes maize, wheat, rice, and sorghum and many forage crops. The main product of sugarcane is sucrose, which accumulates in the stalk internodes. Sucrose, extracted and purified in specialized mill factories, is used as raw material in human food industries or is fermented to produce ethanol. Ethanol is produced on a large scale by the Brazilian sugarcane industry. Sugarcane is the world's largest crop. In 2014, 
FAO estimates it was cultivated on about 23.8 million hectares, in more than 90 countries, with a worldwide harvest of 1.69 billion tonnes. Brazil was the largest producer of sugar cane in the world. The next five major producers, in decreasing amounts of production, were India, China, Thailand, Pakistan and Mexico.

The world demand for sugar is the primary driver of sugarcane agriculture. Cane accounts for $80 \%$ of sugar produced; most of the rest is made from sugarbeets. Sugarcane predominantly grows in the tropical and subtropical regions, and sugar beet predominantly grows in colder temperate regions of the world. Other than sugar, products derived from sugarcane include falernum, molasses, rum, cachaça (a traditional spirit from Brazil), bagasse and ethanol. In some regions, people use sugarcane reeds to make pens, mats, screens, and thatch. The young unexpanded inflorescence of tebutelor is eaten raw, steamed or toasted, and prepared in various ways in certain island communities of Indonesia.

In India, between the sixth and fourth centuries BC, the Persians, followed by the Greeks, discovered the famous "reeds that produce honey without bees". They adopted and then spread sugar and sugarcane agriculture. A few merchants began to trade in sugar - a luxury and an expensive spice until the $18^{\text {th }}$ century. Before the $18^{\text {th }}$ century, cultivation of sugarcane was largely confined to India. Sugarcane plantations, like cotton farms, were a major driver of large human migrations in the $19^{\text {th }}$ and early $20^{\text {th }}$ century, influencing the ethnic mix, political conflicts and cultural evolution of various Caribbean, South American, Indian Ocean and Pacific island nations. Sugarcane is a tropical, perennial grass that forms lateral shoots at the base to produce multiple stems, typically three to four metres high and about five $\mathrm{cm}$ in diameter. The stems grow into cane stalk, which when mature constitutes approximately $75 \%$ of the entire plant. A mature stalk is typically composed of 11-16\% fibre, 12-16 $\%$ soluble sugars, 2-3 \% non-sugars, and 63$73 \%$ water. A sugarcane crop is sensitive to the climate, soil type, irrigation, fertilizers, insects, disease control, varieties, and the harvest period. The average yield of cane stalk is $60-70$ tonnes per hectare per year. However, this figure can vary between 30 and 180 tonnes per hectare depending on knowledge and crop management approach used in sugarcane cultivation. Sugarcane is a cash crop, but it is also used as livestock fodder.

\section{By-products of sugarcane}

Other than sugar, products derived from sugarcane includes

Bagasse

Molasses

Spentwash

Ethanol

Pressmud

Trash

Indian sugar industry produces 10-12 m tmolasses, $75-90 \mathrm{~m}$ tbagasse, $8-10 \mathrm{~m}$ tpress mud and $12-15 \mathrm{~m} \mathrm{t}$ oftrash.

\section{Bagasse}

Bagasse, generated as a by-product, fibrous matter that remains after sugarcane crushed to extract juice. Can be used profitably in two ways - for making paper and for the generation of electricity. The manufacture of paper from bagasse is an environmentfriendly, alternative over the conventional route of extracting pulp from trees. Bagasse has a high heat factor, so it is used in the generation of electricity, which substitutes the conventional thermal alternative and eliminates the emission of greenhouse gases. 
After crushing of sugarcane in sugar mills and extraction of juice from prepared cane by milling, discarded fibrous residual matter of cane which come to about $28 \%$ to $30 \%$ by weight of cane, called bagasse. Bagasse is obtained as sugarcane residue. It contains around $50 \%$ moisture and $2 \%$ sugar and balance is fibrous material. Bagasse is very commonly used as fuel in boilers in the sugar mills for production of steam as well as electrical power i.e. cogeneration. The steam is used in the Processing of sugarcane to sugar. It is used in Prime Movers and also in Steam Turbines for Production of Electrical Power for running electrical motors and other power requirements of the sugar mills and sugar mills colony. The surplus power from sugar industry is sold to State Electricity Boards in its Grid for distribution.

Bagasse is used as Raw material by the Paper Industry for Production of Fine Quality paper. Bagasse and wood fibre are made into building particle board by a process analogous to paper making.

For each 10 tonnes of sugarcane crushed, a sugar factory produces nearly 3 tonnes of wet bagasse. Since bagasse is a by-product of the cane sugar industry, the quantity of production in each country is in line with the quantity of sugarcane produced.

The high moisture content of bagasse, typically 40 to $50 \%$, is detrimental to its use as a fuel. In general, bagasse is stored prior to further processing. For electricity production, it is stored under moist conditions, and the mild exothermic reaction that results from the degradation of residual sugars dries the bagasse pile slightly. For paper and pulp production, it is normally stored wet in order to assist in removal of the short pith fibres, which impede the papermaking process, as well as to remove any remaining sugar.
A typical chemical analysis of bagasse might be (on a washed and dried basis):

Cellulose 45-55\%

Hemicellulose 20-25\%

Lignin 18-24\%

Ash 1-4\%

Waxes $<1 \%$

Bagasse is an extremely inhomogeneous material comprising around 30-40 \% of "pith" fibre, which is derived from the core of the plant and is mainly parenchyma material, and "bast", "rind", or "stem" fibre, which comprises the balance and is largely derived from sclerenchyma material. These properties make bagasse particularly problematic for paper manufacture and have been the subject of a large body of literature.

Many research efforts have explored using bagasse as a renewable power generation source and for the production of bio-based materials.

\section{Fuel}

Bagasse is often used as a primary fuel source for sugar mills; when burned in quantity, it produces sufficient heat energy to supply all the needs of a typical sugar mill, with energy to spare. To this end, a secondary use for this waste product is in cogeneration, the use of a fuel source to provide both heat energy, used in the mill, and electricity, which is typically sold on to the consumer electricity grid. The resulting $\mathrm{CO}_{2}$ emissions are equal to the amount of $\mathrm{CO}_{2}$ that the sugarcane plant absorbed from the atmosphere during its growing phase, which makes the process of cogeneration greenhouse gas-neutral. In many countries (such as Australia), sugar factories significantly contribute 'green' power to the electricity supply. For example, Florida Crystals Corporation, one of America's largest sugar companies, owns and operates the 
largest biomass power plant in North America. The $140 \mathrm{MW}$ facility uses bagasse and urban wood waste as fuel to generate enough energy to power its large milling and refining operations as well as supply enough renewable electricity for nearly 60,000 homes.

Ethanol produced from the sugar in sugarcane is a popular fuel in Brazil. The cellulose-rich bagasse is being widely investigated for its potential for producing commercial quantities of cellulosic ethanol. For example, Verenium Corporation is building a cellulosic ethanol plant based on cellulosic by-products like bagasse in Jennings, Louisiana. Bagasse is often used as a primary fuel source for sugar mills; when burned in quantity, it produces sufficient heat energy to supply all the needs of a typical sugar mill, with energy to spare.

\section{Paper}

Around 5-10 \% of paper production worldwide is produced from agricultural crops, valuing agricultural paper production at between $\$ 5$ and 10 billion. One of the most notable of these is bagasse. Paper production is the second-largest revenue stream from bagasse; the largest is electricity cogeneration. Using the by-products of agricultural crops for paper production, rather than wood, does offset commercial forestry practices. This is believed beneficial because the conversion of the rainforest to commercial tree stock and common forestry practices destroys a majority of the indigenous rainforest life forms. For example, the most common commercial tree stock for short fiber pulp for paper is eucalyptus, which is considered an invasive species due to compounds in the leaves that can be toxic in large quantities (i.e. on a tree farm), and because it is considered a fire hazard. A secondary benefit of substituting agricultural by-products for commercial forestry practices is the reduction of the number of farmers following logging roads into the rainforest for the purpose of burning pristine rainforests to convert to farming. It is thought that bagasse has the added advantage over other forms of papermaking feedstock in that it requires fewer greenhouse gases to collect, compared to harvesting of wood chips, as the fibre has already been transported to the factory for extracting the sugar. However, a full lifecycle analysis should be performed before using this claim commercially. Due to the ease with which bagasse can be chemically pulped, bagasse requires less bleaching chemicals than wood pulp to achieve a bright, white sheet of paper. The fibers vary in length depending on the country and cane variety but are typically about 1.3 to $1.7 \mathrm{~mm}$ long. Bagasse fibers are well suited for tissue, corrugating medium, newsprint, and writing paper.

Bagasse pulp and paper mills tend to be smaller than wood-based mills, although many world-scale factories exist. TNPL is the Largest bagasse-based Paper Mill in the world, consuming about one million tones of bagasse every year.

Most chemical bagasse pulp mills concentrate the spent reaction chemicals and combust them to power the paper mills and to recover the reaction chemicals.

\section{Boards}

It can also be used for making boards resembling Plywood or Particle board. It has wide usage for making partitions, furniture etc. It is an eco-friendly method as it does not involve any harm to the world's timber resources, un-like plywood. It is known as Bagasse Board and is considered a good substitute for plywood.

\section{Other uses}

Bagasse's uses are wide and varied due to its widespread availability and low cost. 


\section{Fermented fiber feed}

K-Much Industry has patented a method of converting bagasse into cattle feed by mixing it with molasses and enzymes (such as bromelain) and fermenting it. It is marketed in Thailand, Japan, Malaysia, Korea, Taiwan and Middle East and Australia as "fiber rich". Bagasse is the primary ingredient in WikiCells, an edible food packaging concept that originated at David Edwards' La Laboratoire in Paris.

\section{Health impact}

Workplace exposure to dusts from the processing of bagasse can cause the chronic lung condition pulmonary fibrosis, more specifically referred to as bagassosis.

\section{Co-generation}

Co-generation is the concept of producing two forms of energy from one fuel. One of the forms of energy must always be heat and the other may be electricity or mechanical energy. In a conventional power plant, fuel is burnt in a boiler to generate high-pressure steam. This steam is used to drive a turbine, which in turn drives an alternator through a steam turbine to produce electric power. The exhaust steam is generally condensed to water which goes back to the boiler. As the low-pressure steam has a large quantum of heat which is lost in the process of condensing, the efficiency of conventional power plants is only around $35 \%$.

In a cogeneration plant, very high efficiency levels, in the range of $75 \%-90 \%$, can be reached. This is so, because the low-pressure exhaust steam coming out of the turbine is not condensed, but used for heating purposes in factories or houses. Since co-generation can meet both power and heat needs, it has other advantages as well in the form of significant cost savings for the plant and reduction in emissions of pollutants due to reduced fuel consumption. The potential of power generation from co-generation in India is more than 20,000 MW. Since India is the largest producer of sugar in the world, bagasse-based cogeneration is being promoted.

\section{Benefits of co-generation}

The fuel, bagasse is renewable source of energy.

The sugar industry generates additional power with the bagasse which is used for generation of steam to meet process requirements.

Results in reduced emission levels and global warming and is therefore environment friendly.

Ensures fuel security.

Co-generation project leads to reduction in transmission losses considerably and thus helps in stabilizing the grid voltage because of their proximity to the load centers.

\section{Molasses}

Molasses is a dark brown viscous liquid obtained by centrifuging the massecuite as Byproduct of sugar while processing sugarcane sugar. It contains nearly $45 \%$ uncrystallized, fermentable sugar and some sugrose. It is a valued by-product of the sugar industry. It is used in the manufacture of ethyl alcohol, Indian made foreign liquor (IMFL), as a table syrup and Food Flavourant. It is also used as feed for farm animals and in the manufacture of several processed tobaccos.Molasses can be boiled again in an attempt to crystallize out some of the rich sucrose content of this liquid. However this process is not economical. This will also reduce environmental pollution. The final molasses, which accounts for around 3 to $5 \%$ on quantity of sugarcane crushed. 
Each tablespoon of molasses ( $20 \mathrm{~g}$ ) contains

$58 \mathrm{kcal}(240 \mathrm{~kJ})$,

$14.95 \mathrm{~g}$ of carbohydrates,

$11.1 \mathrm{~g}$ of sugar divided amongst

Sucrose: $5.88 \mathrm{~g}$

Glucose: $2.38 \mathrm{~g}$

Fructose: $2.56 \mathrm{~g}$

Molasses contains no protein or dietary fiber and close to no fat. Molasses can be boiled again in an attempt to crystallize out some of the rich sucrose content of this liquid. However this process is not economical.

Although - Ethanol is also made out of sugarcane molasses in other countries and is being mixed with Petrol to the extent $25 \%$ since long but in India, now the Government has also decided to manufacture Ethanol out of sugarcane molasses and mix it with Petrol to the extent of $5 \%$ and save foreign exchange on one hand and save precious conventional energy source of Petrol one other hand. This will also reduce environmental pollution. Now ethanol is also being manufactured with cane juice.

The final molasses, which accounts for around 3 to $5 \%$ on quantity of sugarcane crushed contains following constituents.

Molasses can be produced from sugarcane, sugar beet, wood sugar and citrus. Here will be described the different types of molasses that can be produced from clarifying, concentrating and/or extracting sucrose from sugarcane juice in a raw sugar factory and from refining raw sugar in a sugar refinery, as well as their primary use in animal feeds. They are: integral or unclarified molasses, high-test molasses, A molasses, B molasses, C (final) molasses and syrup-off.

Integral high-test molasses is produced from unclarified sugarcane juice which has been partially inverted to prevent crystallization, then concentrated by evaporation until approximately $80 \%$ of DM content. Because it is concentrated from unclarified sugarcane juice, heavy incrustations and scum deposits lead to frequent mill interruptions and therefore to increased factory maintenance costs.

High-test molasses is basically the same as integral high-test molasses; however, since the sugarcane juice has been clarified before evaporation and therefore the impurities removed, the negative factors associated with integral high-test molasses are not present.

"A" molasses is an intermediate product obtained upon centrifuging the A masecuite in a raw sugar factory. Approximately $77 \%$ of the total, available, raw sugar in clarified/concentrated sugarcane juice is extracted during this first centifugation process. The "A" molasses, which is produced simultaneously with the "first" or "A" sugar, contains $80-85 \%$ of DM. If used immediately there is no need for partial inversion; however, if it is to be stored it must be partially inverted, otherwise it could crystallize spontaneously in the storage tanks.

"B" molasses is also known as "second" molasses. It, too, is an intermediate product, obtained from boiling together "seed-sugar" and A molasses to obtain a B masecuite, which is then centrifuged to extract an additional $12 \%$ of raw sugar. At this point, approximately $89 \%$ of the total recoverable raw sugar in the processed cane has been extracted. B molasses contains $80-85 \%$ of DM and generally does not crystallize spontaneously; however, this depends on the purity of the original sugarcane juice and the temperature at which it is stored.

The last molasses is known as "C", "final" or "blackstrap" molasses and in some countries as "treacle". It is the end product obtained 
upon combining "virgin" sugar crystals obtained from syrup crystallization and B molasses to form a $\mathrm{C}$ masecuite, which after boiling and centrifuging produces $\mathrm{C}$ sugar and $\mathrm{C}$ molasses. Even though $\mathrm{C}$ molasses is considered the end or final product in a raw sugar factory, it still contains considerable amounts of sucrose (approximately 32 to 42 $\%$ ) which to date has not been recovered by an economically viable method.

Syrup-off, known also as "liquor-off" or "jett", is the end product obtained from the centrifugation of the final refined masecuite in a raw sugar refinery. Normally, syrup-off is sent to the raw sugar (front) section of the refinery where it is reprocessed in order to recover more sucrose. Due to its high content of sucrose, $90-92 \%$ of DM, it is an excellent energy source for monogastrics; however, it can be an expensive option. The decision would necessarily be of an economic nature, including the overall thermal balance of the refinery; it might pay to sacrifice sucrose to save bagasse, or another refinery energy source. Finally, in the process of refining raw sugar, another type of "final" molasses is obtained, called "refinery final molasses" representing less than $1 \%$ of processed raw sugar. Since it has a very similar composition to that of final molasses produced in a raw sugar factory, it is usually deposited in the $\mathrm{C}$ molasses tanks.

In some countries the juice is extracted in a simple animal or mechanical driven press, then boiled in open vats. In this rudimentary process no sucrose crystallization occurs, but rather as the undiluted juice is boiled, the impurities, the coagulated proteins and minerals, surface and are removed to produce a type of molasses called "melote" of $50 \%$ DM. The further boiling, and finally, incorporation of air into the masecuite produces "pan" sugar. In addition to the different types of liquid, cane molasses, dried
C (final) molasses with $91 \%$ DM is a commercial feed ingredient.

There are approximately 60 countries that produce sucrose from sugarcane. Due to cane varieties, climate and different process technologies, the composition of the above described products can vary substantially. For example, in Cuba, the purity, ie, the relation of sucrose to the total DM of the cane juice, can be as high as $88 \%$; in other countries this figure varies from 76 to 80 per cent. An example of the importance of this factor could be the following: B molasses obtained from an initial juice of high purity has a very high probability of crystallizing during storage, whereas A or B molasses obtained from a juice of low purity (78-80\%) will not crystallize during storage. These differences can be important when related to animal feeding systems.

Molasses is used basically as source of energy; it is free of fat and fibre with a low nitrogen content. The nitrogen free extract (NFE), the main fraction representing between $85-95 \%$ of the DM, is composed of a mixture of simple sugars and a non-sugar fraction. The non-sugar fraction is poorly digested and fermented in the gastrointestinal tract. It is the increasing amount of the nonsugar fraction in each successive type of molasses, from $\mathrm{A}$ to $\mathrm{C}$, that determines the nutritional value of molasses for animal feeding.

The amount of the non-sugar fraction as a percent of the total nitrogen free extract DM is: high-test, 9; A molasses, 18; B molasses, 23; and $\mathrm{C}$ molasses, 33 per cent. The amino acids in molasses have not been considered due to their low content in the order of $0.5 \%$ of $\mathrm{AD}$ product. One gallon of syrup-off or A molasses weighs $5.3 \mathrm{Kg}$; the same amount of $\mathrm{B}$ and $\mathrm{C}$ molasses weighs 5.4 and $5.5 \mathrm{Kg}$, respectively. 


\section{Uses of molasses}

Molasses is commonly used with yeast and water in the fermentation process of making rum. It is also used in creating some other alcoholic drinks such as stout and dark ales.

Molasses is added to some brands of tobacco used for smoking (e.g., hookah, shisha, narghile, etc.)

It is mixed into the tobacco with glycerine and flavorings; sometimes it is used with honey and other syrups or fully substituted by them. Brands that use molasses include Mazaya, AlFakher, Nakhla, Tangiers and Salloum.

Some anglers use molasses as a ground bait (also called chum or berley). This is designed to attract fish to the area that an angler is fishing.

In some parts of the world it is used to produce ethanol (ethyl alcohol) for use as an alternative fuel source.

It is used in some horticultural settings to promote microbe activity in the soil.

Molasses is also added to some cattle feed to add essentials vitamins and minerals.

Molasses mixed with other ingredients like maize bran, cotton seed cake, urea, mineral salts and lime.

Molasses in enrichment of dry roughages 1 to $2 \mathrm{k} \mathrm{g}$ of urea and 3 to $5 \mathrm{k} \mathrm{g}$ of molasses dissolved in 20 to 25 liters of water is sprinkled on 1 quintal of chopped dry fodder and fed to animals after $7-8 \mathrm{hrs}$.

1 to $2 \mathrm{~kg}$ of urea +3 to $5 \mathrm{~kg}$ of molasses and 1 to $2 \mathrm{~kg}$ of salt dissolved in 20 to 25 liters of water is sprinkled on 1 quintol of chopped dry fodder and fed to animals after 7 to $8 \mathrm{hrs}$.

\section{Chemical}

Molasses can be used as the carbon source for in situ remediation of chlorinated hydrocarbons.

Molasses is blended with magnesium chloride and used for de-icing.

In Australia, molasses is fermented to produce ethanol for use as an alternative fuel in motor vehicles.

\section{Industrial}

Molasses can be used as a chelating agent to remove rust (mixture of 1 part molasses and 10 parts water).

Ink rollers on printing presses were originally cast using a mixture of molasses and glue.

\section{Molasses}

\section{Low level}

Final molasses is used to improve the palatability of dry feeds where it is often incorporated at levels of between 5 and $15 \%$ (AD) in the final mix. It is used between 5 and $8 \%$ as a binder in pellets and in pre-digested bagasse pith at a level of 15 percent. A solution of three parts of water to one of molasses can be sprayed by plane over parched grass or standing hay to improve palatability and/or leaf loss. This same technique, but hand-sprayed, and with the possible addition of non-protein-nitrogen (NPN), is used to improve the palatability of sugarcane trash when used as a dry season, maintenance ration. Because molasses ferments quickly, it is sometimes added to a silo at a level of $5 \%$ to enhance the fermentative process, as well as to increase palatability. It can also be used at the rate of $50 \mathrm{Kg} / \mathrm{m}^{2}$ as a sealant for horizontal silos. 
The economics related to the commercial use of molasses, together with restricted by-pass protein for intensive beef production has been re-evaluated to the point where molasses, in either liquid or solid form, is currently promoted as a "carrier" for non-proteinnitrogen and other additives (See NONPROTEIN-NITROGEN). Molasses is generally "more available and cheaper" when cattle and sheep are hungriest, ie, when grass is less green; however, when fed alone or mixed with only $3 \%$ of urea, its palatability is not affected and therefore it should be restricted to $2-3 \mathrm{Kg} / \mathrm{head} / \mathrm{day}$. If used as a carrier for higher concentrations of NPN, the bitterness of the urea in the molasses serves as an auto-regulator causing the cattle to consume about one $\mathrm{kg} / \mathrm{head} / \mathrm{day}$. This formula is ( $\mathrm{AD})$ : $\mathrm{C}$ molasses, $80-85 \%$; urea, $10-15 \%$; salt $2.5 \%$ and dicalcium phosphate, 5.5 percent.

Molasses can also be used as a supplement during the rainy season, where it serves to increase carrying capacity rather than improve performance; in this case, the energy obtained from forage is replaced by the more readily fermentable energy from the molasses.

Caution must be taken when the spring rains begin; if the molasses is diluted it will rapidly ferment into alcohol and may fatally poison the cattle. As molasses/urea is deficient in phosphorus, it is necessary to add phosphoric acid to the mixture or provide the cattle with mineral supplementation. Drinking water must be available, constantly.

A multi-nutritional or molasses/urea block can be made by mixing together, and in the following order: final molasses, 50\%; urea, $10 \%$; salt, 5\%; dicalcium phosphate, 5\%; calcium hydroxide, $10 \%$ and lastly, $20 \%$ of a fibre source such as wheat middlings or dried, bagasse pith. Cement may be used instead of hydrated lime but it first must be mixed with
$40 \%$ of its weight in water before adding it to the other ingredients. If possible, the NPN components should be $8 \%$ of urea and $2 \%$ of ammonium sulphate in order to include a source of sulphur for the rumen organisms. Sheep will consume between 150-180 grams/day and cattle approximately $500 \mathrm{~g} /$ day. The block should be with the animals a minimum of 16 hours daily, and preferably 24 hours.

Mixed in drinking water it is used to hydrate baby chicks during the first hours upon arrival from the hatchery. Finally, fresh fish or fishoffal, and snails can be preserved by mixing 50:50 with final molasses, then fed with B molasses to pigs, ducks and geese.

\section{High level}

A commercial beef fattening system, developed in Cuba and still used with modifications after more than 25 years, it is based on free-choice final molasses mixed with $3 \%$ of urea, restricted fish meal or another protein source, restricted forage $(3 \mathrm{Kg}$ $/ 100 \mathrm{Kg} \mathrm{LW}$ ) and free-choice mineral mix of $50 \%$ di-calcium phosphate and salt. The molasses/urea mixture, which represents some $70 \%$ of total diet DM, contains $91 \%$ final molasses and $6.5 \%$ water. The urea and salt are first dissolved in water before being mixed with the molasses; this mix is top-dressed, once daily, generally with $70 \mathrm{~g}$ of bypassprotein (fishmeal) per $100 \mathrm{Kg}$ of live weight.

In a large, feedlot operation, the daily ration/head is calculated in terms of: $90 \mathrm{~g}$ mineral mix, $250 \mathrm{~g}$ fishmeal, $6 \mathrm{Kg}$ molasses/urea and $10 \mathrm{Kg}$ of forage. The ADG can be between 0.8 and $1.0 \mathrm{Kg}$ with a DM conversion of between 10 and 12; however, under average feedlot conditions the gains are between 0.7 and $0.8 \mathrm{Kg} /$ day.

Although molasses can completely replace cereals in a beef feedlot operation, such is not 
the case with milk production, particularly with high producing dairy cows. In this case, the molasses/milk system does not perform adequately. It has been postulated that the problem could be one of insufficient glucose precursors related to the digestion of the molasses, particularly since the demand for this nutrient is greater in milk than in beef.

When fed in large amounts, and incorrectly, molasses may be toxic. The symptoms of molasses toxicity are reduced body temperatures, weakness and rapid breathing. The animals usually have difficulty standing and try to lean against some support with their forelegs crossed. The remedy is to immediately give them a solution that is rich in phosphorus and sodium, and to take the animals off molasses feeding for a few days. The causes of molasses toxicity are most often a scarcity of drinking water in close proximity to where they are being fed or a too rapid switch-over to high molasses diets. A modification to this feeding system is to use restricted grazing, usually one and a half hours, twice daily.

After decades of intense research to improve the performance of swine fed high levels of final molasses, a solution promoted in the early 80's by the Cuban sugar industry, was to simply change from $\mathrm{C}$ molasses to $\mathrm{B}$ molasses; presently, that country uses more than 400 thousand tons of B molasses for animal feeds, annually. Gestating sows are fed a protein supplement and $\mathrm{B}$ molasses to represent $64 \%$ of the DM of the daily diet. The three basic fattening rations, in \% DM, are: 1) treated organic wastes (33), dry ration (33) and B molasses (33); 2) protein supplement (53) and B molasses (47); and 3) "protein molasses": B molasses (70) and Torula yeast cream (30), which as an integral diet of $36 \%$ DM contains $14 \% \mathrm{CP}$ in DM.

Poultry, particularly geese and ducks, can be fattened on liquid diets containing up to $60 \%$ DM of molasses, preferably high-test, A or B molasses. Theoretically, the same system, level and types of molasses work for broilers and layers, however the management factor is crucial. An on-farm, immediate-use, mixing system to include 18 to $24 \% \mathrm{DM}$ of high-test, A or B molasses in dry feeds for poultry is possible.

Two unconventional feeding systems for rabbits using more than 35\% molasses in DM are: 1) "protein molasses" mixed with wheat bran or sun-dried, ground, sugarcane to soak up moisture and 2) "macro-pellets", that use the basic idea of the molasses/urea block but without urea. The air-dry formula for the one kilogram "macro-pellet" is: B molasses or syrup-off, 45-50\%; whole, toasted soybeans, 25\%; mineral mix, 5\%; hydrated lime, 8-10\% and a source of fiber, 10-15 percent. Both feeding systems require an additional $50 \%$ DM of forage.

\section{Press mud or filter cake}

Filter-mud is an industrial waste that has acquired new importance as a compacting and wetting agent in surface silos where $60 \%$ of cane trash is ensiled together with $38 \%$ of filter mud and $2 \%$ urea. Since the trash usually contains $60-70 \%$ DM, the filter mud with $30 \%$ $\mathrm{DM}$ and granular consistency contributes the needed moisture and texture to ensure optimum silage.

Dried filter-mud is also used as a filler in ruminant maintenance diets at a level of 10$30 \%$, along with poultry manure, final molasses, ground cane, urea and minerals. For this purpose the filter mud is sun-dried or dried using heat from chimney escape gases at the sugar factory.

Press Mud is a by-product of sugar industry. For every 100 tonnes of sugarcane crushed about 3 tonnes of press mud cake is left 
behind as by-product. About 5.2 million tonnes of Press mud is being produced in our country every year. Press mud contains sizable quantity of macro and micro nutrients, besides $20-25 \%$ of organic carbon. Press mud is used as manure by sugarcane farmers.

Very recently, in order to get rid of distillery effluent, which is very toxic and very high on BOD and COD contents, is being utilized by spraying and mixing it with press mud. This treatment enriches the press mud in its nutritional values and makes one of the best organic manure. The organic manure made out of Press mud maintains Soil health, sustains sugarcane and sugar production, improves soils physical properties, retains soil moisture and reduce the erosion hazards. Application of enriched press mud, either alone or in conjunction with Bio fertilizers recorded higher sugarcane yield and sugar recovery. This has also mitigated the need to treat the Distillery effluent and save money spent for its treatment.

Press mud contains trace quantity of micronutrients and prevents soil erosion, crusting and cracking, adjust soil $\mathrm{pH}$, improves drainage and promotes normal bacterial and microbial growth in the soil. It is used as both soil reclaimant as well as soil conditioner. Press mud is the most economic soil reclaimant for red loamy soil. It should be broadcasted followed by ploughing and irrigation. Application of press mud at 40t ha1 is reported to reduce the $\mathrm{pH}$ of red loamy soil from 8.55 to 7.60 .

\section{Trash}

Dry leaves, left in field after harvest of sugarcane, are called trash. On an average, a hectare of sugarcane generates about 10 tonnes of trash. Trash contains $28.6 \%$ organic carbon, 0.35 to $0.42 \%$ nitrogen, 0.04 to 0.15 $\%$ phosphorus, 0.50 to $0.42 \%$ potassium.
The sugarcane trash incorporation in the soil influences physical, chemical and biological properties of the soil.

There is a reduction in soil EC, improvement in the water holding capacity, better soil aggregation and thereby improves porosity in the soil.

Sugarcane trash incorporation reduces the bulk density of the soil and there is an increase in infiltration rate and decrease in penetration resistance.

The direct incorporation of chopped trash increases the availability of nutrients leading to soil fertility.

Sugarcane trash can be easily composted by using the fungi like Trichurus, Aspergillus, Penicillium and Trichoderma.

Addition of rock phosphate and gypsum facilitates for quicker decomposition.

The enriched trash compost was also evaluated for its superiority under field conditions using chilli as test crop.

The results indicated that combining trash compost with chemical fertilizers on $50 \%$ basis was more helpful in improving the growth and yield of green chillies as compared to combining FYM in similar proportion or applying the trash compost alone.

The integrated treatments with trash compost resulted in highest green chilli yield (107.57 to $126.27 \mathrm{q} / \mathrm{ha}$ ) as compared to applying it alone (84.44 to $102.39 \mathrm{q} / \mathrm{ha}$ ).

\section{Briquetted charcoal from sugarcane trash}

Dry leaves, left in field after harvest of sugarcane, are called trash. On an average, a hectare of sugarcane generates about 10 
tonnes of trash. Because it has no value as cattle fodder, and because it also resists decomposition, the trash is burnt in situ, in order to clear the field for the next crop. It is estimated that in the state of Maharashtra, more than 4,000,000 tonnes of trash are destroyed in this way. Pyrolysing the trash and converting it into fuel briquettes, can be a very profitable, small scale, rural business.

\section{The process}

The charring kiln, a portable cylindrical structure, about $150 \mathrm{~cm}$ wide and $100 \mathrm{~cm}$ tall) made out of sheet iron is placed in the field where sugarcane harvest is in progress.

The trash is filled into cylindrical metal containers $37.5 \mathrm{~cm}$ wide and $60 \mathrm{~cm}$ tall.

The kiln takes 7 such containers at a time. All containers together accommodate $21 \mathrm{~kg}$ trash.

After loading the containers into the kiln, the top of the kiln is closed with sheet metal lid, which is provided with a chimney.

About $10 \mathrm{~kg}$ trash are burnt underneath the containers (in the kiln) to start the process of pyrolysis. The heat of the trash burning underneath the containers pyrolyses the trash in the container. Pyrolysis gas generated in the process leaves the containers through holes in their bottom, and it too burns, to serve as additional fuel in this process.

Each batch, taking about $40 \mathrm{~min}$ to complete, produces about $7 \mathrm{~kg}$ char $(30 \%$ of the trash filled in the barrels). Three workers can simultaneously operate two kilns to produce about 80-100 kg char daily.

The char is powdered, mixed with a suitable binder, and shaped, with the help of a mold into briquettes. Our mold allows one person to produce daily about $100 \mathrm{~kg}$ briquettes.
The briquettes are laid out in the sun for drying.

\section{Sugarcane tops}

Sugarcane tops (SCT) are a major byproduct of the sugarcane industry which is left in the field after harvest and widely used for feeding draught animals or cattle owned by workers on the sugar estates or by the sugar companies. The 'top' is removed from the cane at a very arbitrary point and this results in important variations in composition, especially of fibre content. Millers hold widely differing opinions on the optimum topping point but the consensus is that it should be at the highest fully formed node. SCT, therefore, consists of 3 distinct parts: the green leaves (blades, the bundle sheath and variable amounts of immature cane.

SCT production varies considerably with variety, age, growing conditions and management practices.

SCT represents up to $18 \%$ of the aerial biomass in Mauritius and Hawaii, giving a conservative estimate of 5 tonnes DM per ha (26\% DM). This is theoretically sufficient to provide forage for 1 livestock unit $(1 \mathrm{LU}=$ $500 \mathrm{~kg}$ ) per ha.

In countries where sugar production is seasonal, livestock depend heavily on SCT, especially in the winter when the productivity of most other forage species is at its lowest. The seasonal availability of SCT, however, represents a constraint on its use and various methods of preservation (ensiling) have been tried.

Sugar-cane tops can be ensiled for better utilization of the large quantities available during the harvest season. Chopped sugarcane tops are easy to ensile and provide a palatable silage. Leaves from the cane plant can be included in the silage, but they lower the 
digestibility. The methods range from small plastic bag silos, below ground trench silos, above ground low-cost silos (1-4 tonnes), small concrete silos (2-6 tonnes) and large concrete silos (100-4000 T).

Loss of ensiled materials is low (5\%) and the quality of the preserved material is very good. Silage made with cane tops and 1-5\% (w/w) molasses and $1 \%$ ammonium sulphate compares very well with temperate crops silage. Preserving cane tops with ammonia, produced in situ from urea, has been successfully applied in small concrete silos (1$4 \mathrm{~T}$ ) at small cowkeeper sites in Mauritius but it is possible to make good silage without additives.

Sugarcane tops are highly palatable with good intake characteristics but are low in protein and require supplementation. Fed on their own animals either lose condition or just maintain themselves or at best have very low levels of production. It has been estimated that SCT can provide for maintenance and 2-4 litres of milk in Mauritius (Sansoucy, 1972). The reasons why low-moderate levels of production are achieved in the latter case is because the small cowkeepers peel the cane tops, keeping the succulent central portion only, and the animals in turn select the succulent bundle sheath and eat very little green leaf. This is achieved by luxury feeding of the cane tops (up to 90 $\mathrm{kg} / \mathrm{head} /$ day) to allow for selection by the animals.

Attempts to improve SCT by alkali treatment or with ammonia/urea does not produce the same improvement in feed value as with cereal straws. Fine chopping decreased, rather than improved intake. Ensiling with urea has the benefit of increasing the nitrogen content and hence the rumen nitrogen balance for cattle. Small silos are an economic method of achieving this, with a requirement of approx 5 tonnes of silage to feed 2 cows for 1 month.
The principles of supplementing SCT-based diets are essentially the same as decribed for whole sugar cane (satisfying the needs of rumen microbes for fermentable nitrogen (ammonia) and trace nutrients, and providing sources of protein, glucose precursors and long chain fatty acids able to bypass the rumen fermentation to balance the needs of production.

Pate [ref] obtained ADGs of $0.52 \mathrm{~kg} /$ day by supplementing SCT with $1 \mathrm{~kg}$ cottonseed meal while animals just maintained weight without it. Ferreiro and Preston [ref] obtained ADG of $0.84 \mathrm{~kg} /$ day when zebu bulls were fed $1 \mathrm{~kg}$ rice polishings with SCT. In Mauritius, SCT silage with $1 \mathrm{~kg}$ copra cake, $0.2 \mathrm{~kg}$ fishmeal, $0.5 \mathrm{~kg}$ rice bran and molasses/urea (3\%) at 3 per $\mathrm{kg}$ per $100 \mathrm{~kg} \mathrm{LW}$ gave ADGs of 0.57$0.67 \mathrm{~kg}$ [Deville et al., ref] but lower gains $(0.41 \mathrm{~kg} /$ day $)$ were obtained with SCT silage, molasses and copra meal [Tuazon]. However, all these results are still below the genetic potential of the animals.

With correct balance of both rumen nitrogen and by-pass nutrients, gains of over $1 \mathrm{~kg}$ per day have been obtained (590) on ad lib SCT and molasses but with different sources of nitrogen: urea, poultry litter and wheat bran. In Mauritius, gains of over $1.4 \mathrm{~kg} /$ day were obtained with finishing beef cattle on $15 \mathrm{~kg}$ SCT silage + molasses/urea (4\%) at $1.5 \mathrm{~kg}$ per $100 \mathrm{~kg} \mathrm{LW}+14 \mathrm{~kg}$ brewers' grains $+1 \mathrm{~kg}$ cottonseed cake.

For milking cows, a UNDP-funded project has demonstrated the benefits of the judicious use of cottonseed cake as a supplement to SCT for small cowkeepers in Mauritius. $1 \mathrm{~kg}$ cottonseed cake in late pregnancy and $0.25 \mathrm{~kg}$ per litre of milk were equally as effective as twice the quantity of commercial concentrates (maize/bran/CSC or GNC etc.). It clearly demonstrated that cow keepers can increase their milk production from 5 litres per day to 
13 litres per day by using the protein supplement.

\section{Spentwash}

Waste water generated by distilleries during the distillation and fermented molasses to ethyl alcohol using specific strains of yeast. It is a dark brown coloured liquid containing residual nutrients from sugarcane and yeast cells does not contain any heavy metals or other toxic residues. Potential polluting agent because

It is highly acidic $(\mathrm{pH}<4.0)$

Has high BOD (45000 - $50000 \mathrm{mg} / \mathrm{l})$ and COD (1-2 lakh mg / 1)

Has high dissolved solids and organic matter content

Hence, it has to be subjected to further treatments before use / disposal

\section{Effluent utilization / disposal options}

Utilization in agriculture:

Pre sowing one time land application

Ferti-irrigation

Composting

Spray drying for production of bio-K

Disposal options:

Concentration and incineration
Direct discharge in to sea

Disposal after RO treatment

In the process of alcohol production, waste generated is known as "spent wash". It contains dissolved solids, mineral salts and high BOD (45,000-55,000 ppm) and COD (90,000-110,000 ppm) values. So its direct application in the field is also problematic. However, it contains $28-30 \%$ organic carbon, $1.89 \% \mathrm{~N}, 0.26 \% \mathrm{P} 2 \mathrm{O} 5$ and $9.45 \% \mathrm{~K} 2 \mathrm{O}$ on solid basis. This spent wash is foul smelling, hot, dark colored and acidic in nature. It is either subjected to biomethanation process to produce biogas or mixed with pressmud and made into compost. Distillery effluent also contains $\mathrm{S}, \mathrm{Ca}$, and high salt load application of $100 \mathrm{~kg} \mathrm{~N} \mathrm{ha}^{-1}$ through spentwash (17.2 q $\left.\mathrm{ha}^{-1}\right)$, was on par with RDN (17.3 q ha $\left.\mathrm{q}^{-1}\right)$ for grain yield of sweet sorghum. (Malagi, 2010).Application of $100 \mathrm{~kg} \mathrm{~N} \mathrm{ha}^{-1}$ through spentwash was found suitable for higher kapas yield (2436.7 $\left.\mathrm{kg} \mathrm{ha}^{-1}\right)$ and quality of Bt cotton compared to RDN through fertilizer (Shyoram, 2011).

\section{Salient findings of one time controlled land application of spentwash}

Build-up of organic carbon, available $\mathrm{N}$ and $\mathrm{K}$ in soils.

Slight increase in EC (0.05 to $0.15 \mathrm{dSm}-1)$ of soils.

No adverse effect on microbial population in soils.

Savings on fertilizer cost up to Rs.1319 in groundnut and Rs. 2307 in chilli. 
Table.1 Physico chemical properties of spent wash

\begin{tabular}{|l|c|c|}
\hline \multicolumn{1}{|c|}{ Characters } & Raw spent wash & Bio methanated spent wash \\
\hline Colour & Reddish Brown & Blackish Brown \\
\hline Odour & Jaggery & Methane \\
\hline pH & $3.03-5.40$ & $6.81-8.76$ \\
\hline EC(dS/m) & $4.93-23.7$ & $7.70-22.2$ \\
\hline BOD(mg/l) & $31400-48079$ & $8652-24682$ \\
\hline COD(mg/l) & $76000-108000$ & $32800-43200$ \\
\hline Total solids $(\%)$ & $2.39-9.89$ & $2.34-7.81$ \\
\hline Total Dissolved solids $(\%)$ & $4.8-8.1$ & $1.2-2.9$ \\
\hline Chloride $(\mathbf{m g} / \mathbf{l})$ & $6381-12496$ & $4467-11995$ \\
\hline Sodium $(\mathbf{m g} / \mathbf{l})$ & $84-3100$ & $42-2156$ \\
\hline Calcium $(\%)$ & $0.08-0.29$ & $0.09-0.23$ \\
\hline Magnesium $(\%)$ & $0.10-0.26$ & $0.03-0.21$ \\
\hline Total $\mathbf{N}_{(\%)}(\%)$ & $0.10-0.36$ & $0.10-0.26$ \\
\hline Total $\mathbf{P}_{2} \mathbf{O}_{5}(\%)$ & $0.01-0.03$ & $0.01-0.02$ \\
\hline Total $\mathrm{K}_{2} \mathbf{O}(\%)$ & $0.42-1.21$ & $0.29-1.56$ \\
\hline
\end{tabular}

\section{Ethanol/alcohol}

Molasses is distilled to produce rectified spirit, extra neutral alcohol, denatured spirit, potable alcohol and ethanol.

Ethanol produced from the sugar in sugarcane is a popular fuel in Brazil.

Although - Ethanol is also made out of sugarcane molasses in other countries and is being mixed with Petrol to the extent $25 \%$ since long but in India, now the Government has also decided to manufacture Ethanol out of sugarcane molasses and mix it with petrol to the extent of 5\% and save foreign exchange on one hand and save precious conventional energy source of Petrol one other hand. Nearly 110 to 120 litres of ethonol is produced per every tonne of cane (Ramaiah, 2008).

\section{Uses of ethanol}

Ethanol is a colorless, flammable liquid which is produced from the fermentation of sugar.
Ethanol is often called 'drinking alcohol' or 'pure alcohol' as it is the prime ingredient in alcoholic beverages. Ethanol is the intoxicating substance in alcohol.

Ethanol can be used as a fuel for motor vehicles. Ethanol makes a good fuel for cars because it reduces the emission of harmful gases such as carbon monoxide.

Brazil is one of the leaders in the production of cars that run on ethanol. Over $20 \%$ of cars in Brazil are able to run on $100 \%$ ethanol fuel.

Lightweight rocket-powered racing aircraft often use ethanol as rocket fuel.

Ethanol is used in antiseptic and some antibacterial soaps and wipes. Ethanol is effective against viruses, fungi and most bacteria but is ineffective against bacterial spores.

As ethanol is soluble in water, it can be used in paint, permanent markers, perfumes and deodorants. 
Ethanol is considered a 'feedstock' into the chemical industry as it is used to make other important chemicals.

\section{Cotton}

Cotton is a soft, fluffy staple fiber that grows in a boll, or protective capsule, around the seeds of cotton plants of the genus Gossypium in the family of Malvaceae. The fiber is almost pure cellulose. Under natural conditions, the cotton bolls will tend to increase the dispersion of the seeds.

The plant is a shrub native to tropical and subtropical regions around the world, including the Americas, Africa, and India. The greatest diversity of wild cotton species is found in Mexico, followed by Australia and Africa. Cotton was independently domesticated in the Old and New Worlds.

The fiber is most often spun into yarn or thread and used to make a soft, breathable textile.

The use of cotton for fabric is known to date to prehistoric times; fragments of cotton fabric dated from $5000 \mathrm{BC}$ have been excavated in Mexico and the Indus Valley Civilization (modern-day Pakistan and some parts of India). Although cultivated since antiquity, it was the invention of the cotton gin that lowered the cost of production that led to its widespread use, and it is the most widely used natural fiber cloth in clothing today.

Cotton plays a vital role in the textile industry. India having largest area under cotton (9 $\mathrm{m} \mathrm{ha}$ ) constituting $26 \%$ of total world cotton area, presently produces $4.59 \mathrm{~m} \mathrm{t}$ (27 million bales) which constitutes $18 \%$ of the world cotton production (Anon., 2012). Byproducts of cotton include stalk, seed, oil and meal.

\section{By-products of cotton}

\section{Cotton stalks}

The conventional manufacturers of both wooden boxes and corrugated boxes are depending on forest resources, for their raw material requirements which are depleting at a high pace. Under such circumstances, recourse has to be taken to find out alternative sources or raw materials. As far as wooden boxes are concerned, forest timber is essential and hence, no alternative can be thought of. With regard to the corrugated boards, one can resort to non-conventional raw materials for manufacture boxes are generally prepared. One such raw material is the cotton plant stalk from which good quality pulp and paper can be prepared.

It is estimated that around 15 million tonnes of cotton plant stalk is generated in our country, annually. At present it is not being used for any commercial purpose, except as fuel by the rural people, while the bulk of stalk produced is disposed off by burning in the field itself. If this agro-waste is stored in the fields, it harbours several insects and pests which can damage the subsequent crop. Hence, it is imperative to lift this agro-waste as early as possible from the fields and put to better use rather than burning it off. Knowhow had been developed at CIRCOT to prepare pulp and paper from cotton plant stalks. Utilising the same knowhow, attempts have been made to prepare soda for preparation of corrugated boards and boxes.

Good quality kraft paper can be prepared by digesting cotton plant stalk chips of about 1.5 $\mathrm{cm}-2.0 \mathrm{~cm}$ size in a rotary digester with $17 \%$ kraft liquor, at $160^{\circ} \mathrm{C}$ temperature for a total period of $5 \frac{1}{2} \mathrm{hr}$ at a material to liquor ratio of 1: 2.5. The cooked material after washing thoroughly could be converted into pulp of desired freeness by mechanically beating it in 
a valley beater. Kraft paper of $120 \mathrm{~g}$ and $140 \mathrm{~g}$ having desired quality parameters could be prepared on a Fourdrinier paper making machine.

\section{Mushroom from cotton stalk}

For successful growing of oyster mushrooms, the substrate has to be processed, i.e. cut to about 3.0-4.0 $\mathrm{cm}$ size and pasteurized at around $80^{\circ} \mathrm{C}$ to ward off the competing moulds. The quality of the spawn decides the yield of sporophores. The yield of fleshy fruiting bodies is normally around $500 \mathrm{~g} / \mathrm{kg}$ of the substrate. The yield of Pleurotus on different substrates is given below.

\section{Cottonseed, meal}

Cottonseed meal is a high protein by-product from the extraction of oil from whole cottonseed. There are two different processing methods used to extract the oil from the cottonseed, and they differ in the amount of oil (fat) they leave in the meal. The amount of oil left in the meal affects its energy value.

\section{Cottonseed, hulls}

Cottonseed hulls are used mostly in the southern area of the U.S. They are low in protein, calcium, phosphorus and energy and high in fiber. Cottonseed hulls are palatable and are used as roughage for cattle, especially in areas where good quality forages are scarce. They occasionally are included in grain mixes to increase the bulk density and crude fiber content. They can be helpful in supporting fat test in low fiber or low roughage rations.

\section{Cottonseed, whole}

Whole cottonseed is high in protein, fat, fiber and energy. This combination of nutrients in one feedstuff is unusual. Whole cottonseed with the lint still attached is white and fuzzy in appearance. It sometimes is called "fuzzy seed," and has the analysis shown below. Whole cottonseed from which the lint has been removed is called delinted seed, is black and smooth in appearance, and tends to be slightly higher in protein and fat than the fuzzy seed.

Cottonseed is one of the important byproducts of cotton, the use of which has not been exploited to the fullest extent.

The seed collected after ginning is used for extraction of oil.

Traditionally, whole cottonseed is used as cattle feed in our country.

\section{Cottonseed oil}

The seed oil extracted from the kernels, after being refined serves as a good edible and nutr itious source. It can be used as cooking oil, salad dressings. It is also highly beneficial for the production of shortening and margarine. Cotton grown for the extraction of cottonseed oil is one of major crops grown around the world for the production of oil, after soy, corn and canola.

Demand of edible oils has necessitated processing of cottonseed for its oil.

Cotton seed contains about $19-22 \%$ of oil depending on the species.

About 68 lakh tonnes of cottonseed produced in our country can yield about 10 lakh tonnes of oil.

The average digestibility of cottonseed oil is $97 \%$ and could be compared with that of soybean, safflower and sunflower oils.

Rich in vitamin E 
Used directly as a cooking medium and also for the manufacture of vanaspati, soap, etc.

\section{Industrial application of cottonseed oil}

Crude cottonseed oil is used in pigment industries, soap making and as lubricating oil.

Refined cottonseed oil is mostly used for manufacturing vanaspati, margarine, edible oil etc.

It can be used for production of acetoglycerides for food brominated oil which is used as wetting agents and for production of cloudy flavoured soft drinks.

The major fatty acids present in cottonseed oil are palmitic, oleic and linoleic.

\section{Production of compost from ginnery waste}

Ginning is the first mechanical operation that the seed cotton undergoes during which the lint is separated from seed. Indian cottons fetch lesser price even in the domestic market as they contain large amounts of trash in baled lint. Foreign cottons being less trashy and contaminant free, Indian mills are resorting to cotton imports. This definitely affects the price of cotton and recently it has been observed that farmers are inclined to switch over to other crops. The sincere efforts of Government of India to modernize market yards and ginning and pressing industries under Mini Mission III and IV of Technology Mission on Cotton have already started showing positive results in producing clean cotton bales on par with international standards. The introduction of pre and post cleaners coupled with other best management practices of machine handling conveying and of cotton produce different kinds of unspinnable cotton wastes and trash in modernized ginning and pressing factories. These units need not be alarmed by this increased waste generated during processing. In fact, the following are the advantages:

Modernized G \& P factories are producing clean cotton which can definitely fetch better price.

The loss incurred during the process, i.e. short fibres and trash can be put to better value addition.

Sugarcane is a multi-product crop and has immense potential for diversification. Byproducts of sugarcane are bagasse, molasses, ethanol, spent wash, pressmud and trash.

Application of $100 \mathrm{~kg} \mathrm{~N}$ ha-1 through spentwash was on par with RDN through fertilizers for higher yield and quality of sweet sorghum and Bt cotton.

Green energy in cogeneration reduces pollution and energy cost to the sugar industries.

Byproducts of cotton include linter, hull, oil and cake were utilized for manufacture of industrially important products. Hull and cake can be used for cattle feed as well as for various other industrial purposes. Oil can be used for edible purpose, for production of vanaspati, salad oil, margarine and soaps etc.

\section{References}

Anonymous, 2011a, Cooperative Sugar. 43(4).

Anonymous, 2011b, Vision-2030: IISRPerspection Plan, Indian Institute of Sugarcane Research, Lucknow. p3.

Bagasse - Britannica Online Encyclopedia.

Covey, Rainey and Shore (2006). The potential for bagasse pulping in Australia, AppitaJ.59:1 17-22.

FAO, 2014, http://faostat.fao.org/site/567/D. 
Farid Ansari, Ajay K., Awasthi and Bhawana P., Srivastava, 2012, Physico-chemical characterization of distillery effluent and its dilution effect at different levels. Archives of Applied Sci. Res., 4(4): 1705-1715.

Jayachandran, M., Sudhakar, G., Nasir Ahmed, S. and Ravichandran, V. K., 2003, Studies on organic mulches and herbicides for weed control in sugarcane. SISSTA, Sugar J., 41-44.

Malagi, M. T., 2010, Effect of spent wash and tillage on growth, yield and juice quality of sweet sorghum. M. Sc. (Agri.) Thesis, Univ. Agric. Sci., Dharwad, Karnataka (India).

Rainey, (2009) A study into the permeability and compressibility properties of bagasse pulp, PhD thesis, Queensland University of Technology.

Roopashree, D. H., Joshi, M., Lakshmi, T. B., Bai, S. K., Ramesha, Y. M. and Krishnamurthy, D., 2009, Effect of enriched sugarcane trash compost on green chilli yield. J. of Environment and Ecology. 27(4): 1608-1611.

Schenck, S., 2001, Molasses soil amendment for crop improvement and nematode management. Vegetable Report 3, Hawaii Agriculture Research Center.

Shrikumar, V., Mahamuni and Ashok, S. P., 2012, Microbial consortium treatment to distillery spent wash and press mud cake through pit and windrow system of composting. J. of Chem., Biol. and Phys. Sci., 2(2): 847-855.

Shyoram, 2011, Effect of secondary treated distillery spentwash as source of nutrient in $\mathrm{Bt}$ cotton in Northern transitional zone of Karnataka. M. Sc. (Agri.) Thesis, Univ. Agric. Sci., Dharwad, Karnataka (India).

Sodeman, William A (October 1967). "Bagasse Disease of the Lungs - After 25 Years". Chest 52(4): 505-507.

Srinivasamurthy, C. A., 2005, Utilization of distillery spent wash for crop production. UAS-KBDA Newsletter.

\section{How to cite this article:}

Shree Harsha Kumar, S.S., G. Prakasha, D.C. Hanumanthapa and Sharanappa Kuri. 2018. Diversified Use of Byproducts of Sugarcane and Cotton - A Review. Int.J.Curr.Microbiol.App.Sci. 7(03): 1616-1634. doi: https://doi.org/10.20546/ijcmas.2018.703.195 